\title{
Applied Talents Training Mode against the Backdrop of Emerging Engineering Education
}

\author{
Changyou Ma ${ }^{1}$, Yiqun Liu ${ }^{2}$, Pengwei Dong ${ }^{1}$, Guifu Wu ${ }^{1}$, Qisheng Liu ${ }^{1}$, Bingbing Yan $^{1}$, Hong Zhao ${ }^{3}{ }^{*}$ \\ 1 School of Mechanical Engineering, Jiamusi University, Jiamusi, China \\ 2 School of Automotive Engineering, Harbin Institute of Technology, Weihai, China \\ 3 School of Pharmaceutical, Jiamusi University, Jiamusi, China \\ *Corresponding author: mcyazh@126.com
}

\begin{abstract}
With the rapid development of the world economy, the goal of education and the training mode of talents have also changed, and applied talents have become an important factor in social development. In order to solve the problems existing in the cultivation and assessment system of applied talents, this paper carried out engineering education reform for the energy and power engineering of Jiamusi University. This paper studies the four aspects of curriculum system, evaluation system, training mechanism and teacher construction, and proposes the reform and optimization method of applied talent training mode. The results show that this model can improve the ability of student to understand theoretical knowledge, innovation and social practice.
\end{abstract}

Keywords-Applied talents; Higher education; Innovative ability; Emerging engineering education

\section{INTRODUCTION}

Applied talents are mainly applied knowledge instead of scientific discovery and creation of new knowledge. Society has a wide demand for this kind of talent. In the process of social industrialization and even information, the society has a large proportion of the demand for applied talents. It is a mode of talent cultivation which the higher education must pay attention to[1]. Talent demand provides a broad space for the development of institutions of higher learning. Applied talents need to go through a complicated training process, which can also reflect the running level of a university. Due to the importance of the state to applied talents, most universities have changed the former education training mode. Many enterprises have also made adjustments to the selection standards of talents. Further optimization of talent training mode and assessment system is the urgent task of the current domestic education [2].

\section{PRoblems Existing IN TRAining Mode OF APPLIED TALENTS}

\section{A. There is no clear training goal}

Some colleges and universities want to cultivate applied talents. However, the model of talent training is still in the old mode, and the teaching of theoretical knowledge is the first and only the practical use of ability training and comprehensive skills is treated as a supplement to the teaching. Without clear

Educational Science Research Project of Jiamusi University (JKA2013029), Planning subject of Heilongjiang Education Office (GBC1213084), Heilongjiang Province Higher Education Project of Basic Scientifc Research (2017-KYYWF-0568)and Education Teaching Research Project of Jiamusi University (2016JL1013). training objectives, it is not clear what kind of applied talents to train. Examination system is still only through the examination paper to grasp the theoretical knowledge of students[3]. Under such a training mode, the allocation of funds and resources to schools will tend to focus on traditional teaching, which hinders the country's reform of personnel training system.

\section{B. There is no training model of scientific system}

In the current training plan, the contents of the classroom are not evenly distributed. Applied talents not only need excellent creative ability, but also need to grasp a lot of theoretical knowledge and make rational use of them. Some colleges and universities blindly pursue students' exercise of applied ability and lack of standardized theoretical knowledge to guide them[4].

\section{Insufficient investment funds}

In order to cultivate college students with international competitiveness, it is necessary to attach importance to the creative and creative ability of college students. Some scientific research organizations which are instructed by teachers in the university will help to cultivate the students' comprehensive ability.

\section{There is no perfect system of assessment and evaluation}

At present, although many universities attach importance to the cultivation of applied talents, scholarships prefer to set standard system according to the ranking of test results. The evaluation of the school for the students depends entirely on the exam results of the semester, and in this system, many enterprises will also use the students' average test results as a standard for the use of talents[5].

\section{E. There is no perfect recommendation system}

In some schools, there are few channels for cooperative education, and there is not enough close contact with enterprises and society[6]. They are divorced from the core concept of serving the society after all, and have not consulted with the social enterprises in the study of the teaching scheme, which leads to the lack of practicality in the training mode. 


\section{RESEARCH ON APPLIED TALENTS TRAINING MODE IN DEVELOPED COUNTRIES}

The United States has many first-class universities in the world. Most of these universities have developed a scientific model for training talents and constantly improve and optimize in the process of practice. In the United States, the main reason for the replacement of the traditional education model is the increase of the unemployment population caused by the great depression in the early 70s. The number of graduates who are graduating cannot find the job, which makes the education and even the whole society begin to doubt the training model. In this context, the American education community has begun the reform of the educational model, hoping to cultivate a number of applied talents that can serve the society to solve the economic crisis. After years of practice, the United States has explored a set of applied talents training mode. Its merits are summed up in the following three aspects.

\section{A. Definite orientation of applied talents}

As a great science and technology power and an industrial power, the United States needs not only the talented people in the frontier of science, but also the talents with excellent practical ability in the production design. Therefore, the United States has made a clear classification of colleges and universities, because of this classification, different levels of universities have no social status of the high and low points, each university has the style and characteristics of the various universities. The applied university is to train applied talents who serve the society. With clear objectives, the teaching content and evaluation system will also be established.

\section{B. Practical class}

In the United States, the applied universities in the United States generally do not only tend to the dissemination of theoretical knowledge, but pay more attention to learning to use. On the basis of traditional education, a new mode of education, which is similar to independent experiment courses, team project learning and interactive classroom, has been added to the students to master the necessary theoretical knowledge, but also to cultivate student's ability to do handson and independent thinking.

\section{Close contact with social enterprises}

The education of the students in the United States is integrated with the social enterprise, the school is responsible for the theory part, the enterprise is responsible for the skills and the practice part, the student will have the enterprise technical support in the practice, and the enterprise becomes the second class of the students. American universities generally attach great importance to what jobs their students are suitable for, and then focus on training their professional and practical abilities. And this ability can be trained by allowing students to participate in professional practice. Like Stanford University and other famous schools, students are encouraged to take an active part in the practice of the enterprise from the lower grade, to cultivate the students' practical ability through the enterprise, and let the students transform their knowledge into ability. Colleges and universities in the United States usually have specialized agencies equipped with professional personnel to take charge of cooperation between enterprises and universities. The purpose of this educational mode is to train talents with excellent post adaptability.

\section{APPLIED TALENTS TRAINING SYSTEM EXPLORATION}

The establishment of this talents training system is based on the reform of our school's thermal and power engineering majors, to improve students' knowledge structure and spirit of innovation. And improving teachers' engineering practice and practical teaching ability.

\section{A. Establishing a diversified theory course}

At present, on the basis of theoretical knowledge, Chinese colleges and universities should select the theoretical knowledge, simplify the knowledge, instilled the knowledge blindly, and drive the class to teach, which can only reduce the students' enthusiasm for the class. Colleges and universities should have professional teachers to sort out knowledge, from the goal of learning to use, from shallow deep to induce students, to stimulate students' thirst for knowledge, so that students have their own to study the spirit of knowledge. In the course of teaching, a large number of examples should be used to prove the knowledge, let the students know that what they have learned is useful, and it also allows students to better understand the knowledge. Classroom will not be confined to classrooms, but to diversify teaching, it is necessary to step out of the traditional classroom teacher's framework for listening to students. We should transfer the classroom to enterprises, society, laboratories and other places to cultivate students' practical ability and knowledge acquisition ability. In the course of teaching questions, we should not be able to cultivate the students' ability to think independently. For a problem, we should encourage students to think and solve problems in their own way. In order to train students to have their own projects, they do not follow blindly and have the ability of their own opinions. Classroom summaries should enable students to take an active part in feedback, and to give feedback on their own problems and breakthroughs. What should they do after class to master knowledge? To fully mobilize students' enthusiasm for learning, the quality of teaching can be improved, so as to lay a solid foundation for the future application of talents.

\section{B. Improving evaluation and evaluation system}

At present, the evaluation system of colleges and universities in China generally depends on the examination results of students[7]. This system will only hinder the pace of application oriented education reform. The evaluation system for undergraduates should be comprehensive, considering the ability of undergraduates from a multifaceted and multi angle perspective. On the basis of the current theoretical knowledge examination which is generally adopted by Chinese colleges and universities, we can appropriately increase the content of the practice examination, such as the project of scientific research, the relevant professional teachers to carry out the examination evaluation, and take the results into the credits. A course can be composed of several tests, including theoretical knowledge, experimental examination, knowledge application 
examination, innovation application examination and so on. In graduation assessment, not only professional teachers should be evaluated, but also professional personages can be combined to evaluate the ability of the students from the company's standard of judging the ability of the staff. The direction of examination should be changed from rote learning to active learning and independent thinking.

\section{Establishing a cooperative training system for school and enterprise}

Finally, applied talents must serve the society and serve the country. The cultivation of applied talents needs close ties with society[8]. Colleges and universities should have specialized agencies to liaison with major enterprises and formulate appropriate stages to invite students to correspond with professional talents to teach in schools. Schools should also be closely linked with the enterprise society, clear what kind of talents the enterprises need, and what abilities do they require. Clear teaching objectives, create professional classroom, and develop a scientific training system[9]. We should adhere to the training mode of combining theoretical knowledge with practical training. We should strengthen practical teaching, pay attention to the cultivation of students' vocational skills, and strive to improve students' comprehensive vocational ability.

Close ties with enterprises, strengthen students' production practice and social practice, and reform the traditional talent training mode centered on schools and classrooms. For students' internships, they should not only be limited to the senior students, but should be led by the professional teachers from the junior grade to the relevant enterprises to carry out the internship, so that the students can understand the enterprise culture and understand the posts from the lower grade. At the same time, the students generally know what positions they are suitable for, and the purpose is to develop at the University.

\section{Strengthening the construction of applied teaching staff}

In the development trend of applied talents training mode, teachers should make further study and strengthen practical training, which has rich experience in enterprise practice[10]. According to the principle of combining the introduction, training and hiring, a team of diversified applied teachers should be constructed to build the "dual teachers and double ability" professional teachers "which can not only train applied talents, but also carry out the cooperation of production, learning and research."

Guide teachers to deepen the industry, improve the ability of industrial service, and guide teachers to pay attention to the training of students' professional skills, support teachers to participate in the urgent needs of the enterprise research and technology research and development, speed up the transformation, improve the quality of practice teaching. To improve the methods of teacher identification and assessment, to further clarify the standards, to improve the pertinence of teacher training, to improve the professional practice ability of teachers, and to support the corresponding incentive measures and assessment methods, to enhance the enthusiasm and initiative of teachers to improve their professional skills.

\section{Applied Talents Training Mode Practice}

At present, colleges and universities in China are paying more and more attention to the cultivation of students' scientific research ability, and the heavy academic knowledge and examinations have made students unable to participate in scientific research activities. This contradiction can just be solved by the training mode of applied talents proposed in this paper. If the university adopts this model, it will achieve the following effects.

(1) Students will have plenty of time to study and conduct research, learn a lot of practical knowledge and don't worry about their studies.

(2) If the scientific research organization of the university can communicate with the enterprise in real time, the students have a lot of resources to study and research and develop and improve their practical application ability.

(3) This mode allows the school's research team to become a student's classroom, as Fig. 1 shows. So that students are not limited to the theoretical learning level of their professional courses, as shown in Fig. 2.

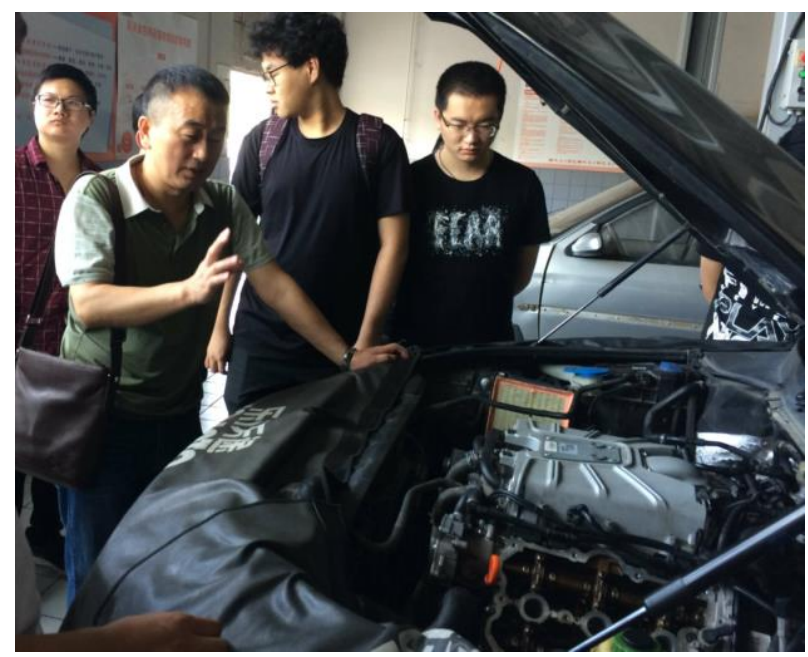

Fig. 1. Research team example.

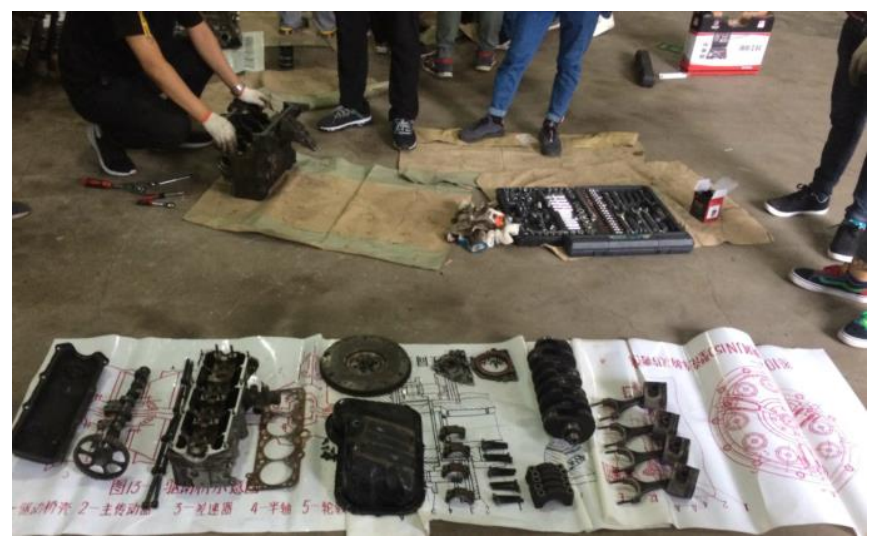

Fig. 2. Practical application ability training. 
(4) Starting from the individualized learning that is conducive to students, from the elective credit system of some electives to the flexible credit system of comprehensive electives, we will continue to innovate and establish a teaching management mechanism that is conducive to the development of students' individuality, and develop a personalized and guiding training program. Establish a credit system education and teaching management system that suits the national conditions. This kind of program will encourage and promote the scientific research team in colleges and universities, so that applied talents have an important position in the university.

\section{CONCLUSIONS}

With the rapid development of the world economy, the competition between the powerful and the powerful countries is also increasingly strong. Since the economic development is inseparable from the application-oriented talents, the importance attached to applied talents in China has been greatly enhanced in recent years. With the support of the state, major universities in China have begun to formulate and implement an application-oriented talent training model. There are bound to be many problems in the process of reform. This paper summarizes these issues, and then compares some of the more scientific talent training models abroad, and develops a set of talent training models that conform to the current national conditions, and then analyzes the application of this talent training model, the actual effect after going to the university research team.

\section{REFERENCES}

[1] Zhong L, Shi J, Zhang W. The Exploration of the " $3+1$ " applied talents' cultivation in mechanical major under the background of excellent engineers training. J Sci Technol Manage Res, 2011, 16: 158-165.

[2] Zhiwei H, Yunfeng B. Professional talents training program exploration in mechanical design manufacturing and automation. J China Adult Educ, 2011, (20): 157-158.

[3] Liang, F., Jiang, G., \& Tan, X. Application type undergraduate mechanical design and manufacture and course system for automation specialty setting. Modern Manufacturing Technology and Equipment, 2012 (2): 62-64.

[4] Li, J., Xu, L., \& Gu, C. Local medical college application type undergraduate course modular education. Chinese Medicine, 2014, (9): 35-36.

[5] Li, W., \& Zhong, K. Research on application oriented talent cultivation scheme of newly established undergraduate colleges and universities. Journal of Chongqing University of Science and Technology (Social Science Edition), 2011, (3): 157-159.

[6] Song, H. Research on the construction of the application oriented undergraduate teaching staff in automotive service engineering. Vocational Education, 2010, (24): 69.

[7] Sun, Z., \& He, W. The quality standard of talent training in New Undergraduate Colleges and universities is explored. Educational Exploration, 2010, (11): 79-80.

[8] Tang, Q., Yu, F., \& Zhang, W. Mechanical specialty application type undergraduate practical teaching reform on. China Electric Power Education, 2013, (2): 151-163.

[9] You, Z., \& Pan, M. Research on the mode of talent cultivation in the context of the research on the development of. Journal of Nanjing University of Science and Technology (Social Science Edition), 2012, 25(4): 108-112.

[10] Zhu, K. The reform of the curriculum system of local applied undergraduate course system. China Electric Power Education, 2010, (3) 104-106. 